\title{
Article \\ Socio-Ecological Support and Physical Facilities Satisfaction: How They Link to Social Participation and Well-Being among Urban Residents in Malaysia
}

\author{
Mohd Mahzan Awang 1,*(D), Alfitri Alfitri ${ }^{2}$, Abdul Razaq Ahmad ${ }^{1}$, Jalal Deen Careemdeen ${ }^{1}$ and Juhari Ahmad ${ }^{3}$ \\ 1 Faculty of Education, The National University of Malaysia, Bangi 43600, Selangor, Malaysia; \\ razaq@ukm.edu.my (A.R.A.); p94548@siswa.ukm.edu.my (J.D.C.) \\ 2 Faculty of Social and Political Science, University of Sriwijaya, Palembang 30862, Sumatera Selatan, Indonesia; \\ alfitri@unsri.ac.id \\ 3 Office of the Executive Director, The Selangor Housing and Property Board, \\ Shah Alam 40503, Selangor, Malaysia; pe@lphs.gov.my \\ * Correspondence: mahzan@ukm.edu.my; Tel.: +60-132-200-471
}

check for

updates

Citation: Awang, M.M.; Alfitri, A.;

Ahmad, A.R.; Careemdeen, J.D.;

Ahmad, J. Socio-Ecological Support and Physical Facilities Satisfaction:

How They Link to Social

Participation and Well-Being among

Urban Residents in Malaysia.

Sustainability 2022, 14, 1184. https://

doi.org/10.3390/su14031184

Academic Editor: Eran Feitelson

Received: 5 November 2021

Accepted: 17 January 2022

Published: 21 January 2022

Publisher's Note: MDPI stays neutral with regard to jurisdictional claims in published maps and institutional affiliations.

Copyright: () 2022 by the authors. Licensee MDPI, Basel, Switzerland. This article is an open access article distributed under the terms and conditions of the Creative Commons Attribution (CC BY) license (https:// creativecommons.org/licenses/by/ $4.0 /)$.

\begin{abstract}
In urban communities, the threat to residents' social well-being arises from their social lives; however, there is little evidence demonstrating how urban communities are connected with each other to improve their well-being. Therefore, the current study aims to identify the satisfaction levels with socio-ecological support and facilities received by selected urban residents in Malaysia. The study also examines the link between residents' satisfaction and their social participation, as well as social well-being. This survey used a set of closed-ended questionnaires. A simple random sampling technique was employed, where a total number of 2502 respondents from six zones participated in this study. The collected data were analysed descriptively and inferentially. The results revealed that the majority of respondents are satisfied with socio-ecological and physical green facilities. Better green infrastructure management practice is required because the results from this study identified scientific issues in green environments in urban recreational centres, waste management, regular health maintenance, landscaping, and building maintenance. Results showed significant differences in the residents' social well-being based on their socio-economic backgrounds. Results also demonstrated that social participation has significantly contributed to the social well-being of urban residents. These findings indicate the importance of various socio-ecological programmes to ensure a positive impact on the social well-being of the urban community. Overall, this study suggests implementing a comprehensive support mechanism for socio-ecological support initiatives to improve the social well-being of urban residents.
\end{abstract}

Keywords: urban; socio-ecological support; green infrastructure; residents; well-being; community; education

\section{Introduction}

Globally, urbanisation has changed the social and cultural landscape in several countries [1]. The social values of community networks have changed rapidly as a result of changes in the city's economic structure [1-5]. Several traditional elements concerning local values (kinship relationship, family values, and feasting ceremonies), as well as culture (family structure, the dynamics of family formation, tendency to have nucleus families instead of extended families), have also undergone rapid changes, especially in this era of digital technology. Urbanisation has resulted in many new settlements, including housing estates, apartments, condominiums, 'Sohos' (Small Office Home Office) and townhouses. Townhouses are a style of multi-floor home that share one to two walls with adjacent properties but have their own entrances. In the suburbs, townhouses are often uniform homes built in a distinct community that might have its own homeowner's association. 
The social structure is also changing, which affects socio-cultural interactions. Therefore, to ensure sustainable development, sustainable urban communities must be developed based on sustainability principles by balancing the economic, social, and environmental aspects [2]. These communities will appreciate, preserve, and conserve the inhabited environment and endeavour to decrease damage to their natural surroundings. Professionals and non-professionals in Poland perceive that tree plantation in urban centres is important because it bring several benefits to residents [3]. In addition, they stimulate sustainable economic growth by providing accessible and competitive employment opportunities that can improve local communities' well-being [4]. A sustainable city can be translated as having an available local security system, such as a neighbourhood watches, which is jointly operated or consented to by community members who must be vigilant and cautious towards outsiders or unfamiliar events. By being vigilant, they can prevent or reduce the risk of undesirable incidents, such as burglary, kidnapping, and child abandonment. In a multi-ethnic urban community, ethnic tolerance is highly required [5].

In numerous developed countries, social values among urban communities are closely linked to educational levels, and social relations are tied to modern values [6]. In fact, in several developed countries, urban housing and residential areas are efficiently managed by municipal authorities. In Asian counties, population diversity is significantly influenced by culture, religion, values, and ethnicities. This leads to unique social relations among urban residents [7]. Several studies have claimed that urbanisation and multi-migration for socio-economic purposes have changed the traditional societal structural. This is in stark contrast to the situation in most developing countries, where some residential areas are unplanned, while some are established by migrants.

This is because several studies on urban communities have focused on subjective well-being without examining the factors that influence social well-being. The current study aims to fill this gap in the literature.

\section{Social Well-Being}

Social well-being refers to the extent to which an individual can interact with other people and feel accepted as a member of the community. Individuals who are socially prosperous will have networks or connections with other individuals and extensive social capital (Putnam's social capital refers to the values of social networking, in which norms and trust will facilitate action and cooperation for mutual benefit) [8]. Today, social networks have expanded through the virtual world, allowing individuals to communicate extensively. The ability to have helpful social networks and interact with various layers of the community allows individuals to have more support. At the same time, the social well-being of individuals can help provide better opportunities for advancement in terms of economic development, as well as mental health. Thus, social well-being refers to a person's ability to make and maintain meaningful positive relationships and have regular contact with other people, including family, friends, neighbours, and co-workers. Good social well-being includes having good relationships and also behaving appropriately to maintain social relationships. It is important to highlight that social well-being is improved by having good social relationships and communication skills, creating and maintaining meaningful relationships, respecting ourselves and others, and creating support systems (with family and friends).

A recent study on social well-being in an urban community in Malaysia highlighted the importance of social inclusion [9] and found that it is closely related to democratic leadership, decision-making practices, and participative culture. Local government is the lowest tier of public administration in a country, and it has limited powers delegated to it by law and/or directives of a higher level of national/federal/central government. Municipal autonomy is a key question of public administration and governance for local government. There are various designated names for local government entities globally including state, province, region, canton, department, county, prefecture, district, city, township, town, borough, parish, municipality, shire, village, ward, and local service district. In China, 
there are several names for a country's administrative divisions: The provincial (province, autonomous region, municipality, and special administrative region); prefecture; county; township; and village [10]. In the United Kingdom, local government has two tiers of local authorities: county councils and district, borough, or city councils. They are responsible for a range of vital services for people, businesses, social care, schools, housing and planning, waste collection, etc. Local government in the United States has at least two tiers: counties and municipalities [11]. The current study was conducted in Malaysia-a developing country in Southeast Asia. Geopolitically, the Malaysian government has three administrative levels: the federal, state, and local governments [12]. Urban communities now anticipate that the government will provide services that are more sophisticated, of higher quality, and more affluent for people of all social classes [13]. Thus, each administrative level has its own responsibilities and jurisdictions. For example, the federal government is responsible for national security, foreign policy, taxation, and education. In contrast, local governments or local authorities are established through legislation, and their activities are restricted to the jurisdiction and duties stipulated in the local government law. Local authorities also perform the role of overseeing and ministering to a district or an area. Their key responsibilities for the community are safeguarding its well-being, sustainability, and planning; implementing and controlling its development; and providing services transparently and fairly. In Peninsular Malaysia, local governments are the authorities in urban areas, rural areas, or a combination of both and are subject to the jurisdiction of state governments.

Several initiatives are being undertaken on a global scale to address urban issues on green infrastructure, including cleanliness, waste management, clean water, drainage systems, infectious diseases, housing complications, traffic congestion, flash floods, water allocation, depletion of water, destruction of property, and urban poverty [14]. The most important thing in urban life is related to the quality of green infrastructure and the extent to which local authorities play a role in the management of a comfortable, prosperous and sustainable urban living ecosystem. In Malaysia, similar initiatives were taken to build a prosperous, competitive urban community that could offer a better quality of life and employ innovative solutions to address urban issues. However, a previous study showed that consistent and ongoing research on social life in urban areas is necessary because of the dynamic nature of urbanisation [15]. Local authorities play a major role in managing an urban living environment while controlling different types of environmental pollution [16]. According to a recent study, the main threat to urban communities' lives and safety arises from the urban community members themselves and results in losses to the community and the ruining of the urban environment [17]. A high-quality life involves transformations that begin with individuals being mindful and practising a healthy lifestyle, being able to fulfil the necessities for survival, and being able to freely develop their potential in society and social systems. Individuals with similar targets form a mutually cooperative and respectable community in a similar environment. However, the extent to which the diverse people in these urban communities can support each other is rarely examined.

\section{Aims of the Study and Methods}

The present study aims to identify the residents' satisfaction regarding socio-ecological support and physical facilities available to urban residents and how these factors have influenced social participation in urban activities. The study further examines social wellbeing among urban residents in Malaysia. The current study also analyses predetermined factors that are contributing factors to social well-being among urban residents.

Socio-ecological support includes support from family members, peers, and local and virtual communities. The physical facilities in this study include the quality of basic facilities provided by local authorities for the use of urban residents. They include a recreation park, public facilities, a recreation centre, a resident parking area, and a pedestrian walkway. The most important elements to the quality of the facilities provided are safety, health, green environment, and hygiene. Green infrastructure in urban residential areas is very important, as any uncontrolled disposal of solid and household waste will have a negative impact 
on quality of life. Drainage and garbage disposal areas need to be managed efficiently to improve the quality of life in the city. Physical facilities and social supports may affect social participation behaviours [18] when community members become acquaintances and work cooperatively to conduct scientific, intellectual, social service, sports, and recreation activitiesto improve social well-being without barriers such as racial, ethnic, or religious differences. The concept of social well-being for urban communities was measured using the standards of personal, social, and environmental security and economic well-being.

The conceptual framework used was a combination of social environment theories, namely Bronfenbrenner's ecological system theory [19] and social capital theory. The quality-of-life theory [20] and residential environment satisfaction determinant model [21] were used to assess quality of life. Bronfenbrenner's ecological system theory defines complex layers of the socio-environment, with each layer affecting an individual's interaction with their socio-environment. It includes five systemic layers of an individual: the microsystem, mesosystem, exosystem, macrosystem, and chronosystem. The microsystem is the closest layer of an individual's social environment; they have primary contact with the people in this layer. The mesosystem involves the principal contexts or environments, such as the cultural values, norms, and gazetted law in which individual development occurs. The exosystem includes the neighbourhood, parents' workplaces, parents' friends, and mass media, all of which are environments that are external to an individual's experience but nonetheless affect them. The macrosystem involves the interconnectedness of the various microsystems, including interconnections among family members, urban life, and working culture. The chronosystem comprises all environmental changes that occur over an individual's lifetime that influence their development, including major life transitions and historical events. This study considered the elements of these layers to gain a clear understanding of how these socio-ecological layers support urban life activities. The community social support in study measures the extent to which individuals perceive that their needs for support, information, and feedback are being fulfilled by friends, by family, by virtual environment, and by the community.

The second theory utilized in this study was Putnam's social capital theory. This theory posits that social networking is valuable, as community members work together with shared norms, values, and understandings that facilitate co-operation within or among groups. The level of social capital can be examined based on the extent to which a community member actively participates in social activities. According to this theory, active participation in social activities binds the social capital, whereas wider social networking in social activities bridges the social capital. In this study, elements of social capital were integrated into the investigation of urban community participation in social activities.

The quality-of-life theory refers to overall human well-being, including the level of satisfaction of needs, happiness, socio-economic stability, and health. In an urban context, an individual's capability to fulfil their needs is closely related to their quality of life. The residential environment satisfaction determinant model focuses four major items: objective characteristics, subjective perceptions, subjective evaluations, and urban domains. In each aspect, satisfaction is evaluated by focusing on community attributes, neighbourhood attributes, housing attributes, and the physical environment. The quality-of-life theory and the residential environment satisfaction determinant model are the major social well-being indicators considered in this study. In this study, the four main indicators in measuring social well-being are as follows: personal happiness, social networking of residents, healthy housing environment, safety and health, and economic sustainability among urban residents. Each of these indicators are quantified by five elements that are included as items in questionnaires. Quantifiers for personal happiness are self-satisfaction, enjoyment, pride in being part of the community, and feeling accepted by the local community. Furthermore, detailed quantifiers for social networking of residents include friendship, social capital, neighbourhood, and community life. The housing environment quantifiers that contribute to social well-being are home facilities that help urban residents to obtain many life needs. Quantifiers for the safety and health elements include hygiene issues and lack of crime. 
Finally, the quantifier for economic sustainability encompasses of how their life in urban areas helps them to survive.

This study used a survey research design. A questionnaire was employed, as it is a reliable research instrument to obtain information from respondents in large populations [22]. The fixed-response questionnaires were assessed as per a 5-point Likert scale, which was reviewed by three experts, and all items in the questionnaire were constructed based on the ecological system theory, social capital theory [23], quality-of-life theory, and residential environment satisfaction determinant model, as well as a relevant literature review [24]. The questionnaire was verified by the content experts. Prior to data collection, a pilot study was conducted involving 100 respondents from the Klang Valley, Malaysia, of whom 40 were Malay, 40 were Chinese, and 20 were Indian. Cronbach's alpha values for all constructs were $>0.800$, indicating that the items can be reliably used for data collection. Because there are debates on the generalisation of the findings from survey data, there are many considerations that need to be taken prior to data collection. For instance, the sample included in a survey has to have similar characteristics to the population. In addition, a total number of samples in survey research is also a prerequisite for the generalisation of the findings from survey data. According to Krejcie \& Morgan's Sampling Table [25], a minimum number of 384 samples are sufficient to represent a population of one million that has similar characteristics. In this study, a total of 2502 respondents were sampled, which is more than the minimum number of samples based on Krejcie \& Morgan's Sampling Table. The study included 2502 respondents, representing the total urban population in Malaysia (16 million), who were selected using a simple random sampling method from six urban zones (municipal councils) in Malaysia. Accordingly, a total of 2502 urban residents from throughout Malaysia (i.e., Majlis Bandaraya Subang Jaya-MPSP, Ampang Jaya Municipal Council-MPAJ, Kajang Municipal Council—MPKJ, Majlis Perbandaran Klang—MPK, Seberang Perai City Council-MPSP, and Selayang Municipal Council-MPS) were selected for the study. When the respondents were selected, their educational qualifications were considered, from the certificate level to doctoral level. Informed consent information was given to all the respondents. All the respondents were given pseudonyms, and we asked them if they consented to participate in this study.

The collected data were then analysed descriptively (mean and standard deviation calculation) to determine the levels of socio-ecological support, physical facilities, social participation, and social well-being. Inferential analyses, such as one-way MANOVA and one-way ANOVA, were used to identify differences in social well-being based on socio-economic background, and multiple regression analysis was used to find out the contribution of socio-ecological support and physical facilities towards social participation and social well-being.

\section{Results}

This study involved 2502 respondents, comprised of 1149 males and 1353 females from urban communities in Malaysia.

\subsection{Demographics of Respondents}

Respondents were asked to indicate their demographic backgrounds in terms of gender, ethnicity, age, income, residential area, and educational level. Accordingly, Table 1 presents the demographic profiles of the respondents, all of whom belong to diverse ethnicities: $54.8 \%$ Malay, $26.5 \%$ Chinese, and $18.7 \%$ Indian. In terms of age, $n=1129$ respondents were 19-30 years old, $n=971$ were 31-50 years old, and $n=402$ were over 50 years old. Concerning their income per month, $n=1468$ respondents earned MYR 1000-3000, $n=755$ earned MYR 3001-5000, and $n=279$ earned more than MYR 5001. Regarding the distribution based on municipal residential areas, $16.7 \%$ of the respondents were from MPSJ, 16.7\% from MPAJ, 16.7\% from MPKJ, 16.7\% from MPK, 16.7\% from MPSP, and $16.7 \%$ from MPS. Regarding education level, $n=1154$ respondents had a certificate, 
$n=864$ had diplomas, $n=312$ had a master's degrees, $n=118$ had bachelor's degrees, and $n=54$ had doctoral degrees.

Table 1. Demographic Profile.

\begin{tabular}{cccc}
\hline Profile & Demographics & Frequency $(\boldsymbol{n})$ & Percentage (\%) \\
\hline \multirow{2}{*}{ Gender } & Male & 1149 & 45.9 \\
& Female & 1353 & 54.1 \\
\hline \multirow{3}{*}{ Ethnicity } & Malay & 1370 & 54.8 \\
& Chinese & 663 & 26.5 \\
& Indian & 469 & 18.7 \\
\hline \multirow{3}{*}{ Age } & 19-30 years & 1129 & 45.1 \\
& 31-50 years & 971 & 38.8 \\
& Above 51 years & 402 & 16.1 \\
\hline \multirow{3}{*}{ Income } & MYR 1000-3000 & 1468 & 58.7 \\
& MYR 3001-5000 & 755 & 30.2 \\
& >MYR 5001 & 279 & 11.2 \\
\hline \multirow{5}{*}{ Residential area } & MPSJ & 417 & 16.7 \\
& MPAJ & 417 & 16.7 \\
& MPKJ & 417 & 16.7 \\
& MPK & 417 & 16.7 \\
& MPSP & 417 & 16.7 \\
& MPS & 417 & 16.7 \\
\hline \multirow{5}{*}{ Educational level } & Certificate & 1154 & 46.1 \\
& Diploma & 864 & 34.5 \\
& Bachelor's degree & 312 & 12.5 \\
& Master's degree & 118 & 4.7 \\
& Doctoral degree & 54 & 2.2 \\
\hline The majority of respondents involved in this study obtained a certificate level of study $(46.1 \%, n=1154)$. Only \\
$6.9 \%$ of the respondents had postgraduate degrees (master's and doctoral).
\end{tabular}

\subsection{Urban Residents' Satisfaction}

\subsubsection{Urban Community Social Support Satisfaction}

A descriptive analysis involving the mean and standard deviation (SD) was conducted to determine the satisfaction levels with socio-ecological support received by urban communities (Table 2). The community social support in the study measures the extent to which individuals perceive that their needs for support, information, and feedback are being fulfilled by friends, by family, by virtual environments, and by the community.

Table 2. Socio-ecological Support received by Urban Residents from Sub-constructs.

\begin{tabular}{lccc}
\hline \multicolumn{1}{c}{ Types of Supports } & Mean & SD & Satisfaction Levels \\
\hline Family Support & 3.56 & 0.74 & Very Satisfied \\
Peer Support & 3.37 & 0.83 & Very Satisfied \\
Local Community Support & 3.68 & 0.94 & Very Satisfied \\
Virtual Community Support & 2.35 & 0.41 & Satisfied \\
\hline
\end{tabular}
(SD = Standard Deviation).

Table 2 presents the descriptive analysis results of the mean scores for each subconstruct in the socio-ecological support category. The majority of residents stated that they were very satisfied with family support; satisfied with peer support; very satisfied with local community support; and satisfied with virtual community support.

Detailed descriptive results of family support (Table A1) showed that the item 'My family supports me in choosing to settle in this area' had the highest mean score (Mean $=3.89$; $\mathrm{SD}=0.98$ ). Meanwhile, the item 'My family reminds me to be careful in being charitable to unfamiliar neighbours' had the lowest mean score (Mean $=2.20$; $\mathrm{SD}=0.85$ ). 
In terms of social support received by urban peers (Table A2), the results demonstrated that the item 'I chose to live here because many of my friends live here' recorded the highest mean score $($ Mean $=3.95 ; \mathrm{SD}=0.95)$. Meanwhile, the lowest mean score was recorded for the item 'I made many new friends of various ethnicities during my stay in this area' (Mean $=1.99 ; \mathrm{SD}=0.68)$.

The majority of urban residents are very satisfied with local community support. Table A1 shows the highest mean score was recorded for the item 'Residents' associations and NGOs exist in this residential area' (Mean $=4.04$; $\mathrm{SD}=0.77$ ). Meanwhile, the lowest mean score was 'The community here always make contacts with the authorities to improve activities' (Mean = 3.55; SD = 1.00).

The majority of residents are satisfied with virtual community support. Table A1 shows that the item 'We have WhatsApp and Telegram groups to strengthen relationships and facilitate communication' had the highest mean score (Mean $=3.81$; SD =0.99). Meanwhile, the item 'LED display is also used to inform the programme conducted for the knowledge of all community members' had the lowest mean score (Mean $=2.04$; SD $=0.73$ ).

\subsubsection{Urban Residents' Satisfaction with Physical Facilities}

A descriptive analysis involving mean and standard deviation was conducted to determine the satisfaction levels of urban communities with their physical facilities.

Table 3 shows that the majority of urban residents are very satisfied with physical facilities. However, the satisfaction level for hygiene had the lowest mean score (Mean $=2.37$; $\mathrm{SD}=0.92$ ). Table A2 shows the item 'Clean drainage system and walkways' at the extremely satisfied level, whereas the item 'Basic facilities are adequate and very pleasing' had the lowest mean score $(\mathrm{Mean}=2.05 ; \mathrm{SD}=0.63)$. This shows that the majority of residents are happy with public amenities. A detailed result shows the highest mean score for item 'I can easily get public transport here' $($ Mean $=4.17$; SD $=0.75)$. Urban residents indicated that they satisfied with safety. The highest mean score was recorded for the item 'I get security assistance easily in times of emergency in the community where I live' (Mean = 3.95; $\mathrm{SD}=0.94)$, whereas the lowest mean score was recorded for the item 'My child does not need supervision while playing outside the house' (Mean $=2.01$; $\mathrm{SD}=0.75$ ). In response to the item 'A hygienic surrounding is maintained well' (Mean $=3.81$; SD =0.98), the majority reported that they are satisfied. A detailed result found that there was slight satisfaction for the item 'The buildings in the area are constantly painted and well maintained' $($ Mean $=2.05 ; \mathrm{SD}=0.71)$. The majority of urban residents seemed to be happy with recreation areas $($ Mean $=3.06 ; \mathrm{SD}=0.88)$.

Table 3. Physical Facilities.

\begin{tabular}{lccc}
\hline \multicolumn{1}{c}{ Aspects } & Mean & SD & Satisfaction Levels \\
\hline Residential & 4.31 & 0.78 & Very Satisfied \\
Satisfaction & 3.58 & 0.92 & Very Satisfied \\
Public amenities & 2.62 & 0.81 & Satisfied \\
Security & 2.37 & 0.75 & Satisfied \\
Hygiene & 3.06 & 0.88 & Very Satisfied \\
Recreation Area & & & \\
\hline
\end{tabular}

\subsection{The Link between Socio-Ecological Support and Social Participation}

Multiple regression analysis was used to ascertain the influence of socio-ecological support on the social participation among urban residents in Malaysia. Table 4 shows that socio-ecological support contributed 29.3\% $(\mathrm{B}=0.799, \mathrm{t}=18.439$, Sig $=0.000$, and $\left.R^{2}=0.293\right)$, whereas physical facilities support contributed $7.3 \%(\mathrm{~B}=0.335, \mathrm{t}=17.438$, Sig $=0.000$, and $R^{2}=0.369$ ) towards social participation in various urban communities. 
Table 4. How Social Support and Physical Support are Linked to Social Participation.

\begin{tabular}{ccccccccc}
\hline \multirow{2}{*}{ Factors } & \multicolumn{2}{c}{ Unstandardised Coefficients } & $\begin{array}{c}\text { Standardised } \\
\text { Coefficients }\end{array}$ & & & Sig. & $\boldsymbol{R}^{\mathbf{2}}$ & Contribution \\
\cline { 2 - 6 } & $\mathbf{B}$ & Standard Error & Beta & & & & \\
\hline Socio-ecological Support & 0.799 & 0.043 & 0.354 & & 18.439 & 0.000 & 0.293 & $29.3 \%$ \\
Physical Facilities & 0.405 & 0.023 & 0.335 & & 17.438 & 0.000 & 0.369 & $7.6 \%$ \\
Constant & -0.403 & 0.113 & & -3.572 & 0.000 & \\
\hline
\end{tabular}

\subsection{Social Well-Being}

A descriptive analysis involving the mean and standard deviation (SD) was conducted to determine the levels of social well-being in urban communities (Table 5). Social well-being in this study means how individuals perceive their level of happiness, social networking, healthy environment, safety and health, and economic sustainability in daily life in the context of urban life.

Table 5. The Levels of Social Well-being.

\begin{tabular}{lccc}
\hline \multicolumn{1}{c}{ Elements } & Mean & SD & Interpretation \\
\hline Happiness & 3.78 & 0.76 & Moderately High \\
Social Networking & 3.68 & 0.76 & Moderately High \\
Healthy Environment & 3.72 & 0.66 & Moderately High \\
Safety \& Health & 2.98 & 0.66 & Moderate \\
Economic Sustainability & 3.00 & 0.86 & Moderately High \\
\hline
\end{tabular}

According to the results, the level of social well-being among urban residents was moderately high. The mean scores were happiness $=3.78$ with $\mathrm{SD}=0.76$, social networking $=3.68$ with $\mathrm{SD}=0.76$, healthy environment $=3.72$ with $\mathrm{SD}=0.66$, safety and health $=2.98$ with $\mathrm{SD}=0.66$; and economic sustainability $=3.00$ with $\mathrm{SD}=0.86$. The lowest level of social well-being was recorded for the element of health and safety. It is fair to state that all the elements of social well-being are interrelated and correlated each other. Urban residents require broad supportive social networks, safety, economic sustainability, and a healthy environment. All of these determine social well-being among urban residents. A healthy environment includes how green infrastructure is managed systematically and effectively in order to produce a better urban life environment. Indeed, green infrastructure is a crucial factor to stimulate COVID-19 pandemic recovery [26].

Differences in Social Well-Being Based on Monthly Income

A one-way MANOVA analysis was carried out to examine the differences of social well-being of urban residents based on their gross monthly income. The Box's M test is a procedural prerequisite in one-way MANOVA analysis to determine the variancecovariance homogeneity matrix.

The results of Box's M analysis showed significant variance-covariance differences among the dependent variables for all levels of independent variables $(\mathrm{F}=6.209, p=0.000)$. That is, the variance covariance of the dependent variable was not homogeneous across all independent variables. However, one-way MANOVA analysis can still be conducted to identify differences based on respondents' monthly gross income, as the present study has a large sample size [27]. Consequently, the results of the one-way MANOVA analysis are as follows.

Table 6 displays the one-way MANOVA analysis results obtained for the mean score comparison of social well-being based on the respondents' gross monthly income [Wilks' $\lambda=0.966, F(3,2352)=6.209$ and $p=0.000(p<0.05)]$. No significant differences were observed regarding the social well-being of urban communities based on their monthly gross income. Next, a multivariate ANOVA analysis was conducted to identify the mean score differences for each element of social well-being based on the gross monthly income of 
the urban residents. The following table compares the mean scores and standard deviations for each element of social well-being based on the respondents' gross monthly income.

Table 6. One-Way MANOVA Social Well-being Differences based on Monthly Income.

\begin{tabular}{cccccc}
\hline Effect & Nilai Wilks' Lambda & F Value & DF between Groups & DF Within Group & Sig. \\
\hline Social Well-being & 0.966 & 6.209 & 3 & 2352 & 0.000 \\
\hline
\end{tabular}

There were significant differences concerning social well-being based on the respondents' gross income (Table 7). For happiness, the F value was 11.293 and the significant value (sig) was 0.000; for social networks, $\mathrm{F}=11.049$ and sig $=0.000$; for a healthy environment, $\mathrm{F}=15.009$ and Sig. = 0.000; for safety and health, $\mathrm{F}=14.243$ and Sig. $=0.000$; and for economic sustainability, $\mathrm{F}=12.013$ and Sig. $=0.000$. To identify the differences in social well-being elements in detail based on the respondents' gross monthly income, a post Hoc Scheffe test was conducted, and the following results were obtained.

Table 7. One-Way ANOVA for Social Well-being Differences based on Monthly Income.

\begin{tabular}{|c|c|c|c|c|c|c|c|c|c|}
\hline Elements & $\begin{array}{l}\text { Gross Monthly } \\
\text { Income }\end{array}$ & $n$ & Mean & SD & $\begin{array}{l}\text { Type III Sum } \\
\text { of Squares }\end{array}$ & DF & $\begin{array}{l}\text { Sum of } \\
\text { Squares }\end{array}$ & $\mathbf{F}$ & Sig. \\
\hline \multirow{4}{*}{ Happiness } & MYR 1000-3000 & 1468 & 3.77 & 0.77 & \multirow{4}{*}{13.183} & \multirow{4}{*}{2} & \multirow{4}{*}{6.591} & \multirow{4}{*}{11.293} & \multirow{4}{*}{0.000} \\
\hline & MYR 3001-5000 & 755 & 3.73 & 0.77 & & & & & \\
\hline & >MYR 5001 & 279 & 3.98 & 0.65 & & & & & \\
\hline & & 2502 & 3.78 & 0.76 & & & & & \\
\hline \multirow{4}{*}{$\begin{array}{c}\text { Social } \\
\text { Networking }\end{array}$} & MYR 1000-3000 & 1468 & 3.64 & 0.78 & \multirow{4}{*}{12.689} & \multirow{4}{*}{2} & \multirow{4}{*}{6.344} & \multirow{4}{*}{11.049} & \multirow{4}{*}{0.000} \\
\hline & MYR 3001-5000 & 755 & 3.70 & 0.71 & & & & & \\
\hline & >MYR 5001 & 279 & 3.87 & 0.73 & & & & & \\
\hline & & 2502 & 3.68 & 0.76 & & & & & \\
\hline \multirow{4}{*}{$\begin{array}{c}\text { Healthy } \\
\text { Environment }\end{array}$} & MYR 1000-3000 & 1468 & 3.69 & 0.67 & \multirow{4}{*}{13.315} & \multirow{4}{*}{2} & \multirow{4}{*}{6.657} & \multirow{4}{*}{15.009} & \multirow{4}{*}{0.000} \\
\hline & MYR 3001-5000 & 755 & 3.71 & 0.67 & & & & & \\
\hline & >MYR 5001 & 279 & 3.93 & 0.61 & & & & & \\
\hline & & 2502 & 3.72 & 0.66 & & & & & \\
\hline \multirow{4}{*}{$\begin{array}{l}\text { Safety \& } \\
\text { Health }\end{array}$} & MYR 1000-3000 & 1468 & 3.75 & 0.69 & \multirow{4}{*}{12.518} & \multirow{4}{*}{2} & \multirow{4}{*}{6.259} & \multirow{4}{*}{14.243} & \multirow{4}{*}{0.000} \\
\hline & MYR 3001-5000 & 755 & 3.80 & 0.63 & & & & & \\
\hline & >MYR 5001 & 279 & 3.98 & 0.58 & & & & & \\
\hline & & 2502 & 3.79 & 0.66 & & & & & \\
\hline \multirow{4}{*}{$\begin{array}{c}\text { Economic } \\
\text { Sustainability }\end{array}$} & MYR 1000-3000 & 1468 & 3.53 & 0.89 & \multirow{4}{*}{17.684} & \multirow{4}{*}{2} & \multirow{4}{*}{8.842} & \multirow{4}{*}{12.013} & \multirow{4}{*}{0.000} \\
\hline & MYR 3001-5000 & 755 & 3.70 & 0.80 & & & & & \\
\hline & >MYR 5001 & 279 & 3.70 & 0.78 & & & & & \\
\hline & & 2502 & 3.60 & 0.86 & & & & & \\
\hline
\end{tabular}

Table 8 shows that significant differences were observed in terms of happiness, social networking, safety and health, and a healthy environment between respondents with a gross monthly income of MYR 1000-3000 and those with the gross monthly income exceeding MYR 5000. Significant differences were also found between respondents earning a gross income of MYR 3001-5000 and those earning a gross income of more than MYR 5000. Regarding economic sustainability, a significant difference was observed between respondents earning a gross monthly income of MYR 1000-3000 and those earning a gross monthly income of more than MYR 5000. 
Table 8. Post Hoc Scheffe Test of Social Well-being Differences based on Monthly Income.

\begin{tabular}{|c|c|c|c|c|c|}
\hline Social Well-Being & $\begin{array}{l}\text { (I) Gross Monthly } \\
\text { Income }\end{array}$ & $\begin{array}{l}\text { (J) Gross Monthly } \\
\text { Income }\end{array}$ & $\begin{array}{c}\text { Mean } \\
\text { Differences (I-J) }\end{array}$ & $\begin{array}{c}\text { Standard } \\
\text { Deviation }\end{array}$ & Sig. \\
\hline \multirow{6}{*}{ Happiness } & \multirow{2}{*}{ MYR 1000-3000 } & MYR 3001-5000 & 0.03 & 0.03 & 0.535 \\
\hline & & >MYR 5001 & -0.21 & 0.04 & 0.000 \\
\hline & \multirow{2}{*}{ MYR 3001-5000 } & MYR 1000-3000 & -0.03 & 0.03 & 0.535 \\
\hline & & >MYR 5001 & -0.24 & 0.05 & 0.000 \\
\hline & \multirow{2}{*}{ >MYR 5001} & MYR 1000-3000 & 0.21 & 0.04 & 0.000 \\
\hline & & MYR 3001-5000 & 0.24 & 0.05 & 0.000 \\
\hline \multirow{6}{*}{ Social Networking } & \multirow{2}{*}{ MYR 1000-3000 } & MYR 3001-5000 & -0.06 & 0.03 & 0.182 \\
\hline & & >MYR 5001 & -0.22 & 0.04 & 0.000 \\
\hline & \multirow{2}{*}{ MYR 3001-5000 } & MYR 1000-3000 & 0.06 & 0.03 & 0.182 \\
\hline & & >MYR 5001 & -0.16 & 0.05 & 0.007 \\
\hline & \multirow{2}{*}{ >MYR 5001} & MYR 1000-3000 & 0.22 & 0.04 & 0.000 \\
\hline & & MYR 3001-5000 & 0.16 & 0.05 & 0.007 \\
\hline \multirow{6}{*}{ Healthy Environment } & \multirow{2}{*}{ MYR 1000-3000 } & MYR 3001-5000 & -0.01 & 0.02 & 0.811 \\
\hline & & >MYR 5001 & -0.23 & 0.04 & 0.000 \\
\hline & \multirow{2}{*}{ MYR 3001-5000 } & MYR 1000-3000 & 0.01 & 0.02 & 0.811 \\
\hline & & >MYR 5001 & -0.21 & 0.04 & 0.000 \\
\hline & \multirow{2}{*}{ >MYR 5001} & MYR 1000-3000 & 0.23 & 0.04 & 0.000 \\
\hline & & MYR 3001-5000 & 0.21 & 0.04 & 0.000 \\
\hline \multirow{6}{*}{ Safety \& Health } & \multirow{2}{*}{ MYR 1000-3000 } & MYR 3001-5000 & -0.05 & 0.02 & 0.178 \\
\hline & & >MYR 5001 & -0.22 & 0.04 & 0.000 \\
\hline & \multirow{2}{*}{ MYR 3001-5000 } & MYR 1000-3000 & 0.05 & 0.02 & 0.178 \\
\hline & & >MYR 5001 & -0.17 & 0.04 & 0.001 \\
\hline & \multirow{2}{*}{ >MYR 5001} & MYR 1000-3000 & 0.22 & 0.04 & 0.000 \\
\hline & & MYR 3001-5000 & 0.17 & 0.04 & 0.001 \\
\hline \multirow{6}{*}{ Economic Sustainability } & \multirow{2}{*}{ MYR 1000-3000 } & MYR 3001-5000 & -0.17 & 0.03 & 0.000 \\
\hline & & >MYR 5001 & -0.17 & 0.05 & 0.010 \\
\hline & \multirow{2}{*}{ MYR 3001-5000 } & MYR 1000-3000 & 0.17 & 0.03 & 0.000 \\
\hline & & >MYR 5001 & -0.00 & 0.06 & 1.000 \\
\hline & \multirow{2}{*}{ >MYR 5001} & MYR 1000-3000 & 0.17 & 0.05 & 0.010 \\
\hline & & MYR 3001-5000 & 0.00 & 0.06 & 1.000 \\
\hline
\end{tabular}

4.5. Influence of Socio-Ecological Support, Physical Facilities, and Social Participation on Well-Being

To examine the extent to which social participation, socio-ecological support, and physical facilities influenced the levels of social well-being, a multiple regression analysis was carried out. Sociological supports include Family Support, Peer Support, Local Community Support, and Virtual Community Support.

Table 9 shows that social participation contributed $46.5 \%(B=0.477, \mathrm{t}=27.823$, $\operatorname{Sig}=0.000$ and $\left.R^{2}=0.465\right)$ towards social well-being. Meanwhile, socio-ecological support contributed $5.4 \%(B=0.211, t=12.028$ and $\mathrm{Sig}=0.000)$ toward social well-being, whereas physical facilities contributed $1.7 \%\left(\mathrm{~B}=0.169, \mathrm{t}=9.718, \mathrm{Sig}=0.000\right.$, and $\left.R^{2}=0.536\right)$. The social participation elements that were assessed in this study are as follows: (i) participation in intellectual activities, including formal and non-formal learning engagement; (ii) participation in social activities, encompassing neighbourhood and friendship activities; (iii) participation in sport and recreational activities; and (iv) participation in environmental activities, such as taking care of cleanliness, recycling campaigns, and practical water usage. 
Table 9. Contributing Factors for Urban Residents' Well-being.

\begin{tabular}{|c|c|c|c|c|c|c|c|}
\hline Factors & B & $\begin{array}{l}\text { Unstandardised } \\
\text { Coefficients } \\
\text { Standard Error }\end{array}$ & $\begin{array}{l}\text { Standardised } \\
\text { Coefficients } \\
\text { Beta }\end{array}$ & $\mathbf{T}$ & Sig. & $R^{2}$ & $\%$ \\
\hline Social Participation & 0.468 & 0.017 & 0.477 & 27.823 & 0.000 & 0.465 & $46.5 \%$ \\
\hline Socio-ecological Support & 0.467 & 0.039 & 0.211 & 12.028 & 0.000 & 0.519 & $1.7 \%$ \\
\hline Physical Facilities & 0.201 & 0.021 & 0.169 & 9.718 & 0.000 & 0.536 & $5.4 \%$ \\
\hline Constant & -0.152 & 0.095 & 0.095 & -1.595 & 0.111 & & \\
\hline
\end{tabular}

\section{Discussion}

According to this study's findings, the majority of urban residents are very satisfied with social support from family and local communities. This is a significant finding, as urbanisation has been criticised in many past studies for being a major factor in weakening social capital. The current findings highlight that, irrespective of urban life, most urban residents still have a satisfactory level of socio-ecological support, especially in terms of family and local community. That is, families and the local community continuously play a positive role in improving social participation and social well-being [28]. The current findings are consistent with those of a previous study, which showed that family and local communities greatly influence a community member's behaviour and lifestyle [29]. The present study's findings also agree with those of Bronfenbrenner's ecological system theory, which asserts that the microsystem and macrosystem layers are significantly influenced by the social life environment.

A detailed analysis of family support revealed the lack of family initiative in encouraging a family member to participate in various local community activities. This is alarming, as an exclusionary attitude towards participating in socio-urban community activities is a sign of unsociable values. Such a lack of social interaction skills and a poor attitude towards forming relationships with neighbours might result from the individual's previous urban life [30]. This is because of the lack of social activities promoting a better rapport among neighbours. As urban residents tend to be too occupied with work commitments, social networking in the neighbourhood might not be a priority for them.

The current study demonstrates that multi-ethnic peers may not provide much encouragement to most urban residents to engage in local community activities. This can be asserted the lack of multi-ethnic activities available for urban communities [31], which is attributable to the lack of leisure activities available for them [32]. Previous research has found that Malay, Chinese and Indian people are more inclined to and comfortable with participating in activities with their neighbours of the same ethnicity. Indeed, cultural distinction is a factor for selecting activities based on their respective ethnicities.

The present study's results also revealed that local community organisations play an active role in conducting socio-cultural activities that promote social well-being. NGOs also encourage local communities to participate in various activities. This is something that local authorities can also implement. This study corroborates the findings of a previous study, which suggested that activities conducted in urban residential areas can increase individuals' awareness and responsibility and help to develop committed and caring members in urban communities [33]. Such activities can help urban individuals who tend to be individualistic or occupied with their own lives feel more connected with their communities.

Another unique feature that this study highlighted is support from the virtual community. The results revealed a moderately low level of support provided by the virtual community. The virtual community should become another world for urban communities to become social and receive emotional support. Several developmental sociologists believe that globalisation provides open spaces for different types of social communication at a global level. However, another study found that even though digital technology facilitates 
large-scale global communication, the level of positive virtual support is still an issue for urban communities [34].

The results also showed that most urban residents are satisfied with the residential place for their family life in terms of drainage maintenance systems, clean walkways, and physical amenities for pedestrians. This study is consistent with a previous study on urban communities, which found that urban communities' well-being is closely linked with the facilities provided to improve the urban communities' comforts in life [35]. It also supports a previous study, which demonstrated that a suitable physical environment that fulfils the population's needs is a key feature for determining urban communities' well-being [36].

However, the basic physical facilities that should be completely and satisfactorily provided for residents to improve their well-being are still prompt moderately low levels of satisfaction. This implies that residents are dissatisfied with the lack of proper physical facilities provided by the local municipal councils, which should be improved upon to enhance residents' well-being in the city. This finding differs from that of a previous study which showed that regularly well-maintained physical facilities provide a sense of comfort to the community, which allows them to ultimately attain well-being in life [37].

Overall, the public facilities provided by municipal councils for the urban community's well-being are at a moderately high level. This indicates that the accessibility and management of various public amenities, such as public transportation, parking areas, and health facilities, which have been furnished, meet the needs of the local population. This study confirms a previous study on urban life which stated that efficient public transport facilities in urban areas can help urban residents save time, work efficiently, and reduce emotional stress [38].

In terms of physical facilities, however, the availability of rubbish bins and systematic and organised waste disposal prompted a low level of satisfaction. Therefore, on average, residents are dissatisfied with waste management in their areas. This finding supports a previous study on urban environments, according to which the federal and state authorities are facing issues in managing waste disposal effectively [39]. Finding solutions to such problems requires long-term planning and high-tech approaches, which are widely used in developed countries.

Provision of amenities and facilities in the recreational area, which is one of the factors determining the urban community's well-being, prompted a moderately high level of satisfaction. Thus, the facilities provided for residents' use, such as recreational areas suitable for all ages and recreational and play areas suitable for children, were appreciated by the residents. Facilities in urban communities must encourage community members to become involved in more physical activities. Local authorities are supposed to conduct health promotional programmes to raise awareness and educate and engage urban communities in lifestyle-enhancing behaviours [40].

Regarding the availability of modern, up-to-date, adequate, and suitable equipment for the population, physical recreational facilities and playgrounds prompted a moderately low level of satisfaction. These facilities, which are part of the factors necessary to improve the urban communities' well-being, are not adequate for the local community to use. Proper recreational facilities in urban areas are essential. Urban residents need such places for recreational activities, as they have very limited spaces in their homes or lack access to other recreational spaces [41]. Recreational activities are also a factor in improving urban residents' well-being. Through such activities, the urban community can improve their life satisfaction and happiness and help reduce the risk of psychological illnesses [42].

Furthermore, hygiene in urban communities prompted only a moderate level of satisfaction, especially in terms of hygiene management, a clean environment, and wellmaintained and tidy surrounding buildings. This reveals the areas to which either the municipal council or the local community has given less attention. Therefore, it is necessary for the municipal councils to cooperate with the local community to improve important aspects such as cleanliness and cheerfulness. Without the awareness of the local community, 
enforcement will not be effective in addressing the issues of green infrastructure, cleanliness, a clean environment, and well-maintained and tidy surrounding buildings.

Results from this study highlight the need for green infrastructure management improvement. The majority of respondents reported that they were not very satisfied with waste management, regular health maintenance, and landscaping and building maintenance. Thus, on average, urban residents were dissatisfied with these aspects, as they did not find the areas where they lived very pleasing. This can disrupt their well-being considerably, especially in terms of their living environment and emotional well-being. This study agrees with previous studies, which showed that the maintenance of residential areas and mismanagement of hygiene environments can affect urban dwellers' mental and physical health [43]. As there are various new technological preventive measures to help control diseases, such as dengue, in urban areas, most urban communities face a social dilemma in accepting some new preventive measures [44]. This can affect the level of social well-being among urban residents.

There are at least three main foundations to a good urban recreation park: the extent to which the facilities provided can be used for all ages, a green environment, and safety of use. In order to analyse the usability levels of recreational amenities, the current study surveyed selected urban residents the suitability of the recreational equipment provided for the needs of all ages. In addition, the residents were asked for their responses in regards to green environments and infrastructure, including hygienic issues, cleanliness, and comfortability aspects. These elements are very important, as a green environment for urban communities is clearly stipulated in the National Policy on the Environment to promote economic, social, and cultural progress through an environmentally sound, sustainable development in order to enhance the quality of life of Malaysians. The spirit if the policy is to achieve a clean, safe, healthy, and productive environment for present and future generations. It also aims at promoting effective participation by all sectors of society and sustainable lifestyles and patterns of consumption and production [45]. COVID-19 has changed urban life and social well-being rapidly. Therefore, the Asian Development Bank has identified three pillars for green recovery strategies: leverage scarce government funds as best as possible, accelerate protection of natural resources and climate resilience, and, finally, mitigate heightened project risk perception to catalyse private finance.

According to the results of this study, socio-ecological support significantly influences participation in social activities. Social support, whether from family, peers, the local community or the virtual community, needs to be mobilised to ensure the active participation of the urban community in various activities [46]. This is particularly important because participation in social activities has the highest influence on social well-being. In order to improve well-being through green infrastructure, four integrated clusters have been identified by the Asian Development Bank: health care for economic growth, climateresilient infrastructure to reduce pollution, natural capital to reduce future pandemics, and "resilience bonds" to raise global capital for investment.

\section{Conclusions}

The present study determined that the urban communities in Malaysia have an adequate level of social support and physical facilities and a satisfactory level of well-being. However, further evaluation of the data showed that certain aspects need further improvement, especially regarding virtual support, which is still considered problematic. This is also true for the state of cleanliness in these residential areas and the feeling of safety, which needs to be improved by the authorities. These social and physical supports are particularly important because, as proven in this study, both contribute to the social participation of urban residents. The study also showed that active participation in social activities can improve the social well-being of the urban population. Therefore, more efforts need to be made so that the residents of the urban community can be actively involved in various activities. As the population in urban communities has a unique and complex social and 
economic structure, various social participation models need to be developed to improve the social well-being of the urban population.

This study also provided findings concerning the physical support provided to mobilise the community to use the available facilities, improve their well-being, and become more involved in social activities. This can influence the residents' social participation in community areas and have a clear impact on the well-being of urban residents. This study also added value to Bronfenbrenner's ecological system theory, which only focuses on the influence of the family, community, peers, and institutional environment. The current study added environmental influence on virtual activities carried out by individuals, communities, and peers, thereby strengthening the theory of ecology. The virtual environment also influences individual and community behaviours. Based on Bronfenbrenner's theory, the environment closest to adult communities is the most distant layer, from the microsystem layer to the chronosystem layer. The time dimension represented by technology and communication in the chronosystem layer can become the closest layer to an individual. This situation has challenged the ideas presented in the ecological system theory.

This study further reinforces the ecological system theory, which has proven that the microsystem and macrosystem layers considerably influence the urban communities' residents' behaviours and lives. This study has also strengthened Putnam's social capital theory, which states that social participation and community activities contribute to urban communities' well-being. Therefore, the more consistently the community participates in social activities, the closer they will come to achieving better well-being, especially in urban areas. According to Putnam's theory, social participation that involves environmental sustainability can create a broader bonding dimension and relationships that will lead to a happier community, environment, and life. This shows that the urban community is socially connected, making residents' lives more connected (bonding) to the conducive socio-environment. The government, including local municipal authorities, should thus strive to have a concrete development plan and initiative to improve the well-being of urban societies.

Author Contributions: Conceptualisation, M.M.A. and A.R.A.; methodology, M.M.A. and A.R.A.; software, A.R.A. and J.D.C.; validation, M.M.A. and A.A.; formal analysis, M.M.A. and A.A.; investigation, J.A.; resources, A.R.A. and J.A.; data curation, A.R.A.; writing-original draft preparation, M.M.A. and J.D.C.; writing-review and editing, M.M.A. and J.D.C.; visualisation, M.M.A. and J.D.C.; supervision, M.M.A. and A.R.A.; project administration, A.A. and J.A; funding acquisition, M.M.A., J.A. and A.A. All authors have read and agreed to the published version of the manuscript.

Funding: This research was funded by the National University of Malaysia: GG-2021-021 and University of Sriwijaya, Indonesia: GG-2018-013. The APC was funded by the Faculty of Education, the National University of Malaysia PP-FPEND-2021 and UKM GG-2021-021.

Institutional Review Board Statement: Not applicable.

Informed Consent Statement: Informed consent was obtained from all subjects involved in the study. Written informed consent to publish the article has been obtained from the respondents in this study.

Data Availability Statement: Not applicable.

Conflicts of Interest: The authors declare no conflict of interest. 


\section{Appendix A Comprehensive Results Tables}

Table A1. The Levels of Socio-ecological Support.

\begin{tabular}{|c|c|c|c|}
\hline Family Support & Mean & SD & Interpretation \\
\hline My family supports me in choosing to settle in this area. & 3.89 & 0.98 & Moderately High \\
\hline $\begin{array}{l}\text { My family has always supported me to be involved in local } \\
\text { community activities. }\end{array}$ & 3.81 & 0.85 & Moderately High \\
\hline I live in this area because it is close to my family. & 3.88 & 0.87 & Moderately High \\
\hline $\begin{array}{l}\text { My family encourages me to interact with people from various } \\
\text { ethnicities in my neighbourhood. }\end{array}$ & 3.67 & 0.99 & Moderately High \\
\hline $\begin{array}{l}\text { My family supports me to participate in charitable and volunteer } \\
\text { activities in the community where I live. }\end{array}$ & 3.90 & 0.84 & Moderately High \\
\hline $\begin{array}{l}\text { My family reminds me to be careful in being charitable to } \\
\text { unfamiliar neighbours. }\end{array}$ & 2.20 & 0.85 & Moderate \\
\hline Overall Mean & 3.56 & 0.51 & Moderately High \\
\hline Peer Support & Mean & SD & Interpretation \\
\hline I chose to live here because many of my friends live here. & 3.95 & 0.95 & Moderately High \\
\hline $\begin{array}{l}\text { Most of my friends support my involvement in local } \\
\text { community activities. }\end{array}$ & 2.03 & 0.65 & Moderate \\
\hline $\begin{array}{l}\text { Peers in this neighbourhood often give us encouragement to } \\
\text { live peacefully. }\end{array}$ & 2.03 & 0.72 & Moderate \\
\hline $\begin{array}{l}\text { It is easy for me to contact my friends at home in managing my } \\
\text { daily life. }\end{array}$ & 3.65 & 0.98 & Moderately High \\
\hline $\begin{array}{l}\text { I made many new friends of various ethnicities during my stay in } \\
\text { this area. }\end{array}$ & 1.99 & 0.68 & Moderately Low \\
\hline $\begin{array}{l}\text { When I need a friend, my peers are always there for me to } \\
\text { chat with. }\end{array}$ & 3.68 & 1.00 & Moderately High \\
\hline Overall Mean & 3.37 & 0.83 & Moderately High \\
\hline Local Community Support & Mean & SD & Interpretation \\
\hline Residents' associations and NGOs exist in this residential area. & 4.04 & 0.77 & Highest \\
\hline $\begin{array}{l}\text { Residents' associations and NGOs here conduct activities } \\
\text { together actively. }\end{array}$ & 3.59 & 0.95 & Moderately High \\
\hline $\begin{array}{l}\text { The community members in this area are always concerned about } \\
\text { other residents. }\end{array}$ & 3.56 & 1.00 & Moderately High \\
\hline The residents here plan many activities together. & 3.58 & 0.99 & Moderately High \\
\hline $\begin{array}{l}\text { The community here always make contact with the authorities to } \\
\text { improve activities. }\end{array}$ & 3.55 & 1.00 & Moderately High \\
\hline $\begin{array}{l}\text { The local community works together to maintain the cleanliness } \\
\text { of the residential premises. }\end{array}$ & 3.74 & 0.94 & Moderately High \\
\hline Overall Mean & 3.68 & 0.94 & Moderately High \\
\hline Virtual Community Support & Mean & SD & Interpretation \\
\hline $\begin{array}{l}\text { We use WhatsApp and Telegram groups to reinforce rapport and } \\
\text { facilitate communication. }\end{array}$ & 3.81 & 0.99 & Moderately High \\
\hline I upload pictures of activities in this neighbourhood community. & 2.06 & 0.70 & Moderate \\
\hline $\begin{array}{l}\text { I always share beneficial information with community members } \\
\text { on my social media, such as Facebook and Instagram. }\end{array}$ & 2.07 & 0.71 & Moderate \\
\hline $\begin{array}{l}\text { My social media friends encourage me to be involved in the local } \\
\text { community activities. }\end{array}$ & 2.05 & 0.71 & Moderate \\
\hline $\begin{array}{l}\text { Websites or blogs are available and constantly updated for the } \\
\text { local community. }\end{array}$ & 2.09 & 0.70 & Moderate \\
\hline $\begin{array}{l}\text { LED displays are also used to inform all community members } \\
\text { about programmes organised. }\end{array}$ & 2.04 & 0.73 & Moderate \\
\hline Overall Mean & 2.35 & 0.41 & Moderate \\
\hline
\end{tabular}


Table A2. The Levels of Physical Facilities Support.

\begin{tabular}{|c|c|c|c|}
\hline Residential Satisfaction & Mean & SD & Interpretation \\
\hline This residential area is really proper for my family and me. & 4.21 & 0.84 & Highest \\
\hline Basic facilities are adequate and very pleasing. & 2.05 & 0.63 & Moderate \\
\hline House interiors and neighbourhood spaces are excellent. & 4.00 & 0.73 & Moderately High \\
\hline My residential area is not well-maintained. & 3.68 & 0.91 & Moderately High \\
\hline Clean drainage system and walkways. & 4.24 & 0.42 & Highest \\
\hline Walkways are well-prepared and meet the local community's needs. & 4.03 & 0.80 & Highest \\
\hline Overall Mean & 4.31 & 0.78 & Moderately High \\
\hline Public Amenities & Mean & SD & Interpretation \\
\hline I can easily get public transport here. & 4.17 & 0.75 & Highest \\
\hline $\begin{array}{l}\text { In this area, worshipping places meet the needs of the majority of the } \\
\text { local community. }\end{array}$ & 3.86 & 0.90 & Moderately High \\
\hline There is not enough parking space for residents. & 3.93 & 0.95 & Moderately High \\
\hline Health and educational facilities are effortlessly accessible. & 3.81 & 0.88 & Moderately High \\
\hline Garbage bins and landfills are maintained. & 1.98 & 0.70 & Moderately Low \\
\hline Various public facilities in my residence are adequate and well provided. & 3.73 & 0.92 & Moderately High \\
\hline Overall Mean & 3.58 & 0.92 & Moderately High \\
\hline Safety & Mean & SD & Interpretation \\
\hline $\begin{array}{l}\text { I get security assistance easily in times of emergency in the community } \\
\text { where I live. }\end{array}$ & 3.95 & 0.94 & Moderately High \\
\hline The residential security committee functions actively. & 3.58 & 0.94 & Moderately High \\
\hline Residential security alarms at the have been activated and are functioning. & 2.04 & 0.73 & Moderate \\
\hline Crime rarely happens in this area. & 2.06 & 0.74 & Moderate \\
\hline My child does not need supervision while playing outside the house. & 2.01 & 0.75 & Moderate \\
\hline Security services continuously patrol the neighbourhood. & 2.06 & 0.73 & Moderate \\
\hline Overall Mean & 2.62 & 0.81 & Moderate \\
\hline Hygiene & Mean & SD & Interpretation \\
\hline A hygienic surrounding is maintained well. & 3.81 & 0.98 & Moderately High \\
\hline Rubbish piles up exceedingly and is not collected. & 2.12 & 0.69 & Moderate \\
\hline Mosquito-control fogging is irregular in this area. & 2.10 & 0.73 & Moderate \\
\hline The landscape prepared for this area is nice and attractive. & 2.09 & 0.69 & Moderate \\
\hline $\begin{array}{l}\text { Cooperative activities for cleaning up the areas together are } \\
\text { frequently done. }\end{array}$ & 2.06 & 0.69 & Moderate \\
\hline The buildings in the area are constantly painted and well maintained. & 2.05 & 0.71 & Moderate \\
\hline Overall Mean & 2.37 & 0.75 & Moderate \\
\hline Recreation Areas & Mean & SD & Interpretation \\
\hline $\begin{array}{l}\text { Recreational areas provided are suitable for the needs of residents of } \\
\text { all ages. }\end{array}$ & 4.07 & 0.77 & Highest \\
\hline $\begin{array}{l}\text { Places for relaxation (chairs, benches, etc.) are available in my } \\
\text { residential area. }\end{array}$ & 3.73 & 0.87 & Moderately High \\
\hline $\begin{array}{l}\text { No suitable areas are available for jogging because of a dense population } \\
\text { and non-strategic placements of the buildings. }\end{array}$ & 2.06 & 0.73 & Moderate \\
\hline A children's playground is available adjacent to residences. & 3.71 & 0.97 & Moderately High \\
\hline $\begin{array}{l}\text { The adjacent recreational area is sophisticated, up-to-date, } \\
\text { and contemporary. }\end{array}$ & 2.02 & 0.72 & Moderate \\
\hline $\begin{array}{l}\text { Gym facilities and game courts in this residential area are places for } \\
\text { residents to meet and conduct activities. }\end{array}$ & 2.77 & 1.22 & Moderate \\
\hline Overall Mean & 3.06 & 0.88 & Moderately High \\
\hline
\end{tabular}

\section{References}

1. Zeng, C.; Deng, X.; Dong, J.; Hu, P. Urbanization and Sustainability: Comparison of the Processes in "BIC" Countries. Sustainability 2016, 8, 400. [CrossRef]

2. Jarah, S.H.A.; Zhou, B.; Abdullah, R.J.; Lu, Y.; Yu, W. Urbanization and Urban Sprawl Issues in City Structure: A Case of the Sulaymaniah Iraqi Kurdistan Region. Sustainability 2019, 11, 485. [CrossRef] 
3. Suchocka, M.; Jankowski, P.; Błaszczyk, M. Perception of Urban Trees by Polish Tree Professionals vs. Nonprofessionals. Sustainability 2019, 11, 211. [CrossRef]

4. Zelazna, A.; Bojar, M.; Bojar, E. Corporate Social Responsibility towards the Environment in Lublin Region, Poland: A Comparative Study of 2009 and 2019. Sustainability 2020, 12, 4463. [CrossRef]

5. Ahmad, A.R.; Rahman, A.A.A.; Awang, M.M.; Chew, F.P. Influencing factors of ethnic tolerance among multi-ethnic youths Issues and Trends. Interdisciplinary Behavior and Social Science. In Proceedings of the 6th International Congress on Interdisciplinary Behavior and Social Science 2017 (ICIBSoS 2017), Bali, Indonesia, 22-23 July 2017; pp. 93-98.

6. Basiago, A.D. Economic, social, and environmental sustainability in development theory and urban planning practice. Environmentalist 1999, 19, 145-161. [CrossRef]

7. Bhugra, D.; Becker, M.A. Migration, cultural bereavement and cultural identity. World Psychiatry 2005, 4, 18.

8. Awang, M.M.; Mahmud, Z.; Amat, S.; Ahmad, A.R.; Mohd Ehwan, N.F. Refining indicators for measuring social capital index. Int. J. Innov. Creat. Change 2019, 7, 64-79.

9. Malek, J.A.; Lim, S.B.; Yigitcanlar, T. Social Inclusion Indicators for Building Citizen-Centric Smart Cities: A Systematic Literature Review. Sustainability 2021, 13, 376. [CrossRef]

10. China Internet Information Center. China's Political System the Local Administrative System. Available online: http://www. china.org.cn/english/Political/28842.htm (accessed on 4 November 2021).

11. Owens, S.D. Individual State Descriptions. Washington; US Census Bureau: Washington, DC, USA, 2002.

12. Muslim, N.; Hassan, W.Z.W.; Alias, J.; Mat, N.; Ibrahim, A. Malaysian Federal Constitution from Constitutional Sociology Contexts. ARPN J. Eng. Appl. Sci. 2019, 14, 3761-3770. [CrossRef]

13. Julia, M.S.; Husniyati, M.A.; Suhaiza, I. Factors Influencing the Efficiency of Malaysian Local Governments. Asian J. Account. Perspect. 2020, 13, 40-56. [CrossRef]

14. Daw, M.M.; Ali, E.R.; Toriman, M.E. Determinants of urban residential Water Demand in Libya. Int. J. Eng. Adv. Technol. 2019, 8, 847-856. [CrossRef]

15. Rosehan, N.S.; Abas, A.; Aiyub, K. Studies on the cultural ecosystem services in Malacca city. Plan. Malays. 2020, 18, 133-144 [CrossRef]

16. Masseran, N.; Razali, A.; Ibrahim, K.; Latif, M.T. Modeling Air Quality in Main Cities of Peninsular Malaysia by Using a Generalized Pareto Model. Renew. Sustain. Energy Rev. 2016, 56, 1419-1430. [CrossRef]

17. Goswami, H. Social relationships and children's subjective well-being. Soc. Indic. Res. 2012, 107, 575-586. [CrossRef]

18. Awang, M.M.; Jindal-Snape, D.; Barber, T. A Systematic Review of Theoretical Foundations for Pedagogical Strategies to Promote Positive Behavior. New Educ. Rev. 2019, 58, 133-143. [CrossRef]

19. Ventegodt, S.; Lindholt, J.S.; Henneberg, E. Development and validation of QOL5 for clinical databases. A short, global and generic questionnaire based on an integrated theory of the quality of life. Eur. J. Surg. 2002, 168, 107-111.

20. Amerigo, M.; Aragones, J. A Theoretical and Methodological. Approach to the Study of Residential Satisfaction. J. Environ. Psychol. 1997, 17, 47-57. [CrossRef]

21. Choon, S.W.; Siwar, C.; Pereira, J.J.; Jemain, A.A.; Hashim, H.S.; Hadi, A.S. A sustainable city index for Malaysia. Int. J. Sustain. Dev. World Ecol. 2011, 18, 28-35. [CrossRef]

22. Putnam, R.D. Social capital. Measurement and consequences. Can. J. Policy Res. 2001, 2, 41-51.

23. Rahman, A.A.; Ahmad, A.R.; Malek, J.A.; Awang, M.M. Social Participation and Values Culturalisation Through Non-Formal Learning among Urban Residents of Putrajaya. Kaji. Malays. 2016, 34, 75-100. [CrossRef]

24. Latiff, Z.A. Power-Law Behaviors of the Duration Size of Unhealthy Air Pollution Events. Stoch. Environ. Res. Risk Assess. 2001, 35, 1499-1508.

25. Krejcie, R.V.; Morgan, D.W. Determining Sample Size for Research Activities. Educational and Psychological Measurement. Small-Sample Techniques. NEA Res. Bulletin. 1970, 30, 607-610.

26. Asian Development Bank. Green Finance Strategies for Post-Covid-19 Economic Recovery in Southeast Asia-Greening Recoveries for People and Planet Philippine. Available online: https:/ /www.switch-asia.eu/site/assets/files/2813/green-finance-postcovid-19-southeast-asia.pdf (accessed on the 4 November 2021).

27. Pallant, J. SPSS Survival Manual-A Step by Step Guide to Data Analysis Using SPSS for Windows, 3rd ed.; Open University Press: Maidenhead, UK, 2007.

28. Ahmad, J.; Ahmad, A.R.; Malek, J.A.; Ahmad, N.A.I.L. Social Support and Social Participation among Urban Community in Malaysia. Int. J. Acad. Res. Bus. Soc. Sci. 2018, 8, 418-428. [CrossRef]

29. Jalaluddin, A.M.; Abdul, R.A.; Mohd, M.A.; Juhari, A.; Alfitri, A. Sustainable Environmental Management and Preservation Knowledge among Multi-ethnic Residents. Asian J. Sci. Res. 2014, 7, 546-560.

30. Awang, M.M.; Ahmad, A.R.; Mumpuniarti; Rahman, A.A.A. Social integration practices among multi-ethnic youths. Kasetsart J. Soc. Sci. 2019, 40, 454-458.

31. Van den Berg, P.; Timmermans, H. A Multi-Level Path Analysis of Social Networks and Social Interaction in the Neighborhood. J. ERSA 2015, 2, 55-66.

32. Shamsul, A.B. One State, Three Legal Systems: Social Cohesion in a Multi-ethnic and Multi-religious Malaysia. Boundaries Relig. Freedom: Regul. Relig. Divers. Societies. 2015, 1, 17-30. 
33. Shamsul, A.B.; Daud, S. Nation, ethnicity, and contending discourse in the Malaysian state. Available online: https://www. researchgate.net/publication/275974938_Nation_ethnicity_and_contending_discourse_in_the_Malaysian_state (accessed on the 4 November 2021).

34. Murphy, B.L. Locating Social Capital in Resilient Community-Level Emergency Management. Nat. Hazards 2007, 41, 283-295. [CrossRef]

35. Arslan, T.V.; Durak, S.; Aytac, D.O. Attaining SDG11: Can sustainability assessment tools be used for improved transformation of neighborhoods in historic city centers? Nat. Resour. Forum 2016, 40, 180-202. [CrossRef]

36. Balducci, A.; Checchi, D. Happiness and quality of city life: The case of Milan, the richest Italian city. Int. Plan. Stud. 2009, 14, 25-64. [CrossRef]

37. Amin, H.M.; Fauzi, N.F.M.; Saat, N.Z.M.; Rajab, N.F. Relationship between Physical Activity and Cardiovascular Risk Factors: A Cross-Sectional Study among Low-Income Housewives in Kuala Lumpur. Int. J. Environ. Res. Public Health 2021, $18,6090$.

38. Awuah, K.G.B.; Booth, C.A. Integrated management framework for sustainable cities: Insights into multiple concepts and principles. WIT Trans. Ecol. Environ. 2014, 191, 111-123.

39. Hassan, W.Z.W.; Alias, J.; Muslim, N.; Mat, N. The inculcation of civilization values as the medium towards the holistic development in Malaysia in the era of industrial revolution 4.0. Univers. J. Educ. Res. 2020, 8, 785-793. [CrossRef]

40. Erik, B.; Ragnar, W.; Per, L. Housing Type and Neighborhood Safety Behaviour Predicts Self-rated Health, Psychological Wellbeing and Frequency of Recent Unhealthy Days: A Comparative Cross-sectional Study of the General Population in Sweden. Plan. Pract. Res. 2017, 32, 444-465. [CrossRef]

41. Mohamad, M.S.; Ibrahim, R.; Mokhtar, D.M.; Subhi, N. Youth-to-youth engagement. Int. J. Recent Technol. Eng. $2019,8,38-42$.

42. Yaacob, M.; Amin, L.; Arham, A.F.; Ahmadianhosseini, S. Stakeholders Attitudes to Outdoor Residual Spraying Technique for Dengue Control In Malaysia: A PLS-SEM Approach. PLOS Negl. Trop. Dis. 2021, 15, e0009493.

43. Lim, S.B.; Kong, Y.C.; Rashid, M.F.A.; Malek, J.A. A framework of challenges facing the safe city programme in Kuala Lumpur. Plan. Malays. 2020, 18, 47-61. [CrossRef]

44. Malek, J.A.; Baharudin, R.A. Smart City (SC)-Smart Village (SC) and the 'Rurban' concept from a Malaysia-Indonesia perspective. Available online: https:/ / philarchive.org/archive/MALSCS-3 (accessed on the 4 November 2021).

45. Ministry of Environment and Water Malaysia. Malaysia-National Policy on the Environment. 2018. Available online: https: / / www.doe.gov.my/portalv1/en/tentang-jas/pengenalan/dasar-alam-sekitar (accessed on 4 November 2021).

46. Song, S.J.; Tan, K.H.; Awang, M.M. Generic Digital Equity Model in Education: Mobile-Assisted Personalized Learning (MAPL) through e-Modules. Sustainability 2021, 13, 11115. [CrossRef] 